\title{
Research Status of Carbon Anode and Its Modification for Microbial Fuel Cell
}

\section{Fan Liping, Xu Dandan}

College of Environment and Safety Engineering, Shenyang University of Chemical Technology, Shenyang, China

\section{Email address:}

flpsd@163.com (Fan Liping)

\section{To cite this article:}

Fan Liping, Xu Dandan. Research Status of Carbon Anode and Its Modification for Microbial Fuel Cell. International Journal of Energy and Power Engineering. Vol. 4, No. 6, 2015, pp. 358-361. doi: 10.11648/j.ijepe.20150406.15

Abstract: Anode material and its structure have important influence on the performance of microbial fuel cell. This paper reviews the development of carbon anode of microbial fuel cell briefly, describes the general trend of its improved method, and the research status of the anode modification of microbial fuel cell is introduced from two aspects, which are body modification of anode material and anode modification with external modifying group.

Keywords: Microbial Fuel Cell, Anode, Modification

\section{微生物燃料电池碳基阳极及其改性研究现状}

柇立萍, 徐丹丹

沈阳化工大学 环境与安全工程学院, 沈阳, 中国

\section{邮箱}

flpsd@163. com（訤立萍）

摘要：阳极材料及其结构对微生物燃料电池性能具有重要影响。简要概括了微生物燃料电池阳极材料基本发展情况, 阐述了改进方法的总体趋势, 并分别从阳极材料的本体修饰及阳极材料本体进行外接修饰基团等方面, 介绍了目前微 生物燃料电池阳极修饰改性的研究现状。

关键词: 微生物然料电池, 阳极, 改性

\section{1. 引言}

由于化石能源存储量的逐渐匮乏, 清洁能源的发展得 到越来越多的关注。微生物燃料电池作为新型能源已成为 近年来的研究热点。微生物燃料电池是污水处理与产电功 能兼顾的电化学装置, 借助微生物的催化作用, 将废水中 的有机能转化为电能。电极是微生物燃料电池的重要组成 部分。阳极作为微生物生长及电子收集的重要部位, 其材 料及结构将直接影响到微生物燃料电池的产电性能和污 水处理效果 [1-3]。阳极材料的设计、选择、制备及修饰 将对优化微生物燃料电池的性能产生重要作用 [4]。优良
的微生物燃料电池阳极材料必须满足价廉、吸附性好、抗 腐蚀、亲水、无生物毒性和高电导率等要求 $[5,6]$ 。目前 的研究水平下, 电极材料的昂贵低效仍然是制约微生物燃 料电池广泛应用的最大挑战之一。实现阳极材料的价廉高 效, 是解决微生物燃料电池应用瓶颈的一个有效途径。

\section{2. 碳基阳极材料}

碳基材料因其低成本、强生物适应性及良好的导电性, 成为目前微生物燃料电池研究中使用最广泛的一类阳极 材料 [7]。最常用的碳基材料包括碳纸、碳毡、碳布、碳 棒、碳颗粒、柔性石墨等。Lefebvre等将碳布粘贴在阳极 
室顶部作为微生物燃料电池阳极, 研究阳极液盐度对微生 物燃料电池性能的影响 [8]; Yazdi等用活性碳布作为阳极, 提出了一种可在废物处理过程中实现串并联发电的易操 作微生物燃料电池堆 [9]; 梁鹏等将碳毡与碳纸烧结一体 作为阳极填料组装成填料型微生物燃料电池 [10]; 朱超等 制作了碳纸和石墨毡组成的复合阳极, 研究对微生物燃料 电池快速处理含偶氮染料废水进行效果研究 [11]; Hou等 构建了一种用多孔碳纸做阳极的单室空气阴极MFC对偶氮 染料进行脱色研究 [12]; Nimje等用碳布作为阳极, 以甘 油作为底物构建单室空气阴极MFC [13]。

碳基材料虽然具有较好的导电性, 但碳元素表面能态 较高, 容易失去电子表现出还原性, 若电子要跃迁到碳电 极上, 则通常需要较高的能量, 造成较大的阳极活化过电 势 [14]。

\section{3. 碳基阳极材料的改性修饰}

\section{1. 基本修饰方法}

制约微生物然料电池产电性能的因素有多种, 其中阳 极作为微生物吸附生长的重要部位, 阳极材料的特性将直 接影响着MFC的产电量。有机物的降解过程中产电微生物 可以产生电子, 产生的电子要跨越一定的能垒才能跃迁到 阳极, 从而形成电流 [15]。通过对阳极进行修饰改性, 使 其具有良好的生物相容性、导电性及化学稳定性, 可以降 低阳极表面的能态, 降低阳极活化过电势, 从而提高MFC 的产电性能。

从目前的研究情况来看, 对阳极进行修饰的基本方法 可分为三大类, 一类是利用表面处理法对阳极材料改性。 氨处理可以使其表面形成含氨的表面官能团, 增加电极表 面的电子数量, 更有利于微生物在电极表面吸附生长; 酸 热处理后的碳基材料表面 $\mathrm{C} / \mathrm{N}$ 比会增加, $\mathrm{C}-0$ 的含量降低, 在不影响微生物正常生长和电子传递能力的前提下, 碳基 材料阳极的弱氮处理可极大促进带负电微生物的吸附, 从 而导致电池功率密度的增加; 电化学氧化法改性, 可以根 据电解液的不同在阳极表面附着上亲水官能团（如羧基、 羟基等), 还可以提高表面积和孔隙率, 这些都有助于提 升电极的电化学性能, 进而提高电极性能。

阳极修饰的第二类方法是采用导电聚合物及其复合 材料修饰阳极。导电聚合物容易在电极表面形成导电性好 且活化损失小的纳米颗粒, 用其修饰阳极, 可以使阳极的 活化内阻降低, 增加阳极的表面积, 有利于更多的微生物 吸附在电极上, 提升其性能。

阳极修饰的第三类方法是利用金属或金属化合物涂 层修饰阳极, 同样可以改进MFC的性能。金属离子可以起 到电子传递中间介体的作用, 还有利于金属还原菌在阳极 表面的生长和富集; 活泼金属或其氧化物分散固载在如碳 质等载体上, 制备成催化剂来修饰电极也能使电池性能提 高。

\section{2. 阳极材料本体修饰}

阳极材料的本体修饰即是采用一定的方法对电极表 面进行活化, 增大活性面积, 使MFC的产电性能有所提高。
包括高温氨化、电化学氧化法、酸热处理等。采用高温氨 化法处理阳极, 可以在阳极表面形成含氨的官能团, 电极 表面的正电荷也会增加, 有利于电极表面的微生物吸附生 长。Wang等用高温氨气处理石墨纤维刷阳极表面, $\mathrm{MFC}$ 最 大输出功率提高, 经过 X-射线光电子能谱分析得到, 其 $\mathrm{N} / \mathrm{C}$ 比增加 [16]; Cheng等则是利用氨气处理了碳布阳极, 提 高了碳布表面的正电荷数 [17], MFC最大输出功率可达到 $1970 \mathrm{~mW} / \mathrm{m}^{2}$ 。采用电化学氧化法能使电极表面产生如羧基 的官能团, 羧基可以与细胞色素上的活性基团形成肽键等 化学键作用, 有利于加快微生物与电极之间的电子耦合 [18]。Tang等在硫酸条件下对石墨毡阳极进行电解处理, 电池的启动时间从 $170 \mathrm{~h}$ 减少到 $70 \mathrm{~h}$, 最大输出功率密度从 $967 \mathrm{~mW} / \mathrm{m}^{2}$ 提高到 $1630 \mathrm{~mW} / \mathrm{m}^{2}$, 库伦效率从 $38.4 \%$ 增加到 $57.1 \%$ 。酸热处理可以增加阳极材料表面的 $\mathrm{C} / \mathrm{N}$ 比, 从而导 致了电池功率密度的增加 [19]。Zhu等采用硝酸处理碳纤 维阳极, $\mathrm{MFC}$ 的产电密度提高了 $58 \%$, 启动时间缩短了 $45 \%$ [20]。Feng等 [21] 用三种方法处理碳纤维刷作为阳极, 即酸浸、加热及酸浸和加热的综合处理, 综合处理的电极 将功率密度提高至 $1370 \mathrm{~mW} / \mathrm{m}^{2}$, 分别比未处理、酸浸、加 热的碳纤维刷阳极提高了 $34 \%$ 、25\%和 $7 \%$ 。Liu等用电化学 方法将石墨烯沉积到碳布上作为MFC的阳极 [22], 由于石 墨烯良好的生物相容性, 有效的提高了MFC的最大功率密 度和能量转化率。

文献中一些主要本体修饰方法及其效果见表 1 。对应 文献 [21] 三种不同处理方法下改性阳极相对于未改性阳 极时的功率密度提高率对比见图1。

表1 阳极材料主要修饰方法及其效果。

\begin{tabular}{lll}
\hline 阳极材料 & 修饰方法 & 主要效果 \\
\hline 碳板 & 高温氨气处理 & $\mathrm{N} / \mathrm{C}$ 比率提高, 功率密度提高 $11.2 \%$ \\
碳布 & 高温氨气处理 & 功率密度提高 $42 \%$, 启动时间缩短 $50 \%$ \\
石墨毛 & 硫酸处理 & 功率密度提高 $68 \%$, 库伦效率提高 $48.7 \%$ \\
碳纤维 & 硝酸处理 & 功率密度提高 $58 \%$, 启动时间缩短 $45 \%$ \\
\hline
\end{tabular}

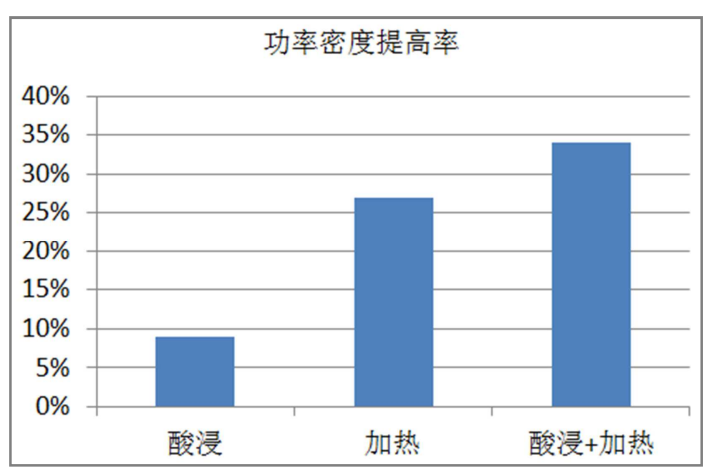

图1 三种不同本体修饰方式下功率密度改善情况。

\section{3. 阳极材料本体外接修饰基团}

阳极材料本体进行外接修饰基团, 可以改变电极表面 的活性基团或者表面空间结构性质等, 进而达到优化MFC 的阳极效率, 如纳米、高分子修饰等。典型的有碳纳米管、 导电聚合物等。Hou等在碳布表面负载石墨烯/聚苯胺纳米 复合物, 得到的最大功率密度为 $1390 \mathrm{~mW} / \mathrm{m}^{2}$, 是未经修饰 碳布的3倍 [23]。Zou等将不停纳米结构的聚吡咯修饰到阳 
极上, 通过比较发现纤维聚吡咯电极的输出功率密度为 $3.4 \mathrm{~mW} / \mathrm{m}^{2}$, 大于球状聚吡咯电极的输出功率密度 3.1 $\mathrm{mW} / \mathrm{m}^{2}[24]$ 。Zhang等使用比表面积为 $265 \mathrm{~m}^{2} / \mathrm{g}$ 的石墨烯对不 锈钢网进行修饰, 作为MFC的阳极, 得到的最大功率密度 为 $2668 \mathrm{~mW} / \mathrm{m}^{2}$, 是以未修饰过的不锈钢网作为阳极的 $M F C$ 的18倍 [25], 这样的结论主要是因为经过石墨烯修饰过的 阳极可以是更多的微生物吸附到阳极表面, 提高MFC的产 电性能。Lowy等研究发现了用添加 $\mathrm{Fe}_{3} \mathrm{O}_{4}$ 或 $\mathrm{Fe}_{3} \mathrm{O}_{4}$ 和 $\mathrm{Ni}^{2+}$ 的石 墨涂层阳极, 其动力学活性比未修饰的阳极高 $1.5 \sim 2.2$ 倍 [26]。Bibiana等通过强阳极氧化作用使石墨毡电极表面 形成了微孔结构, 这种微孔结构可以使电极与底物充分接 触, 对生物膜的形成很有利, 有效提高电流密度 [27]。Lai 等用 $\mathrm{HSO}_{4}{ }^{-}$掺杂聚苯胺来修饰碳布作为阳极, 输出的最大功 率密度为 $1275 \mathrm{~mW} / \mathrm{m}^{2}$, 是未修饰碳布阳极的 2.66 倍 [28], 说明聚苯胺的修饰使可以提高MFC的产电性能的。Qiao等 合成了纳米结构的聚苯胺/二氧化钛复合阳极, 得到的输 出功率密度为 $1495 \mathrm{~mW} / \mathrm{m}^{2}$, 比之前阳极未经修饰的 $M F C$ 的 最大输出功率密度高出 2 倍 [29]。

几种常用外接修饰基团阳极改性方法的主要效果见 表2。

表2 常用外接基团修饰方法及其改性效果。

\begin{tabular}{|c|c|c|}
\hline 阳极材料 & 修饰方法 & 功率密度提高率 \\
\hline 碳布 & 表面涂刷聚苯胺纳米纤维 & $200 \%$ \\
\hline 不锈钢网 & $\begin{array}{l}\text { 表面涂抹石墨烯粉与聚四氟乙烯混 } \\
\text { 合涂料 }\end{array}$ & $180 \%$ \\
\hline 碳纤维 & 表面涂刷纳米结构纤维聚吡咯 & $450 \%$ \\
\hline 石墨片 & 表面粘涂纳米晶磁铁矿 $\mathrm{Fe}_{3} \mathrm{O}_{4}$ & $14.6 \%$ \\
\hline 石墨片 & 表面粘涂纳米晶磁铁矿 $\mathrm{Fe}_{3} \mathrm{O}_{4}+\mathrm{Ni}^{2+}$ & $31.9 \%$ \\
\hline
\end{tabular}

\section{4. 结语}

微生物燃料电池是一种新颖的废水处理与同步发电 技术。阳极材料及其结构是影响微生物燃料电池性能的重 要因素。阳极材料的优化设计、制备及改性是提高微生物 燃料电池发电性能及废水处理效果的有效途径。未来的研 究应着重于高性能阳极材料的开发及修饰改性。寻找生物 催化性强且成本相对较低的阳极修饰材料可以有效降低 电池内阻、加快电子从生物膜表面到达阳极的传递速率。 由于微生物燃料电池涉及生物学、电化学、材料学、环境 科学等诸多领域, 通过各个领域的研究者的不断深入研究, 微生物燃料电池的良好发展前景与应用指日可待。

\section{参考文献}

[1] Zhou MH, Chi ML, Luo JM, He HH, Jin T (2011) An overview of electrode materials in microbial fuel cells. J Power Sources, 196(10): $4427-4435$.

[2] Kim BH, Chang IS, Gadd GM (2007) Challenges in microbial fuel cell development and operation. Appl Microbiol Biotechnol, 76(3) : 485 - 494.
[3] You J, Santoro C, Greenman J, Melhuish C, Cristiani P, Li B, Ieropoulos I. Micro-porous layer (MPL)-based anode for microbial fuel cells [J]. Int $\mathrm{J}$ Hydrogen Energ, 2014, 39 (36) :21811-21818.

[4] 次素琴, 吴娜, 温珍海, 李景虹. 微生物燃料电池电极材 料研究进展, 电化学, 2012, 18(3)：243-251。

[5] 王金金, 李楠, 高宁圣洁, 周启. 微生物燃料电池碳基阳极 材料的研究进展. 中国给水排水, 2012, (28) 22：5-8。

[6] B. E. Logan, B. Hamelers, R. Rozendal, U. Schro “ der, J. Keller, S. Freguia, P. Aelterman, W. Verstraete, K. Rabaey, Microbial fuel cells: methodology and technology, Environ. Sci. Technol. 40 (2006) 5181 5192.

[7] K. Watanabe, Recent developments in microbial fuel cell technologies for sustainable bioenergy, J. Biosci. Bioeng. 6 (2008) $528-536$.

[8] 0 Lefebvre, Z Tan, S Kharkwal, $\mathrm{H} \mathrm{Y} \mathrm{Ng.} \mathrm{Effect} \mathrm{of}$ increasing anodic $\mathrm{NaCl}$ concentration on microbial fuel cell performance. Bioresource Technology, 2012, 112: 336-340.

[9] H Yazdi, L A Gaviria, Z J Ren. Pluggable microbial fuel cell stacks for septic wastewater treatment and electricity production. Bioresource Technology, 2015, 180: 258-263.

[10] 梁鹏, 范明志, 曹效金金, 黄霞, 黄正宏, 王诚. 填料型微 生物燃料电池产电特性的研究 $[\mathrm{J}]$. 环境科学, 2008,29 (2) : 512-517。

[11] 朱超, 解井坤, 易维洁, 高静. 微生物燃料电池快速处理 含偶氮染料废水的研究. 工业水处理, 2015，35(8)：62-65。

[12] Hou B, Sun J, Hu Y Y. Effect of enrichment procedures on performance and microbial diversity of microbial fuel cell for Congo red decolorization and electricity generation. Appl. Microbiol. Biotechnol. , 2011, 90 (4) : 1563-1572.

[13] Nimje V R, Chen C CY, Chen C C, et al. Glycerol degradation in single-chamber microbial fuel cell [J]. Bioresource Technology, 2011, 102 (3) : 2629-2634.

[14] 陈妹琼, 程发良, 郭文显, 张敏, 柳鹏. 微生物燃料电池 阳极材料的最新研究进展. 电源技术, 2015, 39(4): 857-860。

[15] Torres C I, Marcus A K, Lee H S, et al. A kinetic perspective on extracellular electron transfer by anode-respiring bacteria[J] . FEMS Microbiology Reviews, 2010 34(1):3-17.

[16] Wang X, Cheng S A, Feng Y J, et al. Use of carbon mesh anodes and the effect of different pretreatment methods on power production in microbial fuel cells [J]. Environmental Science \& Technology, 2009, 43 (17) : 6870-6874. 
[17] Cheng S A, Logan B E. Ammonia treatment of carbon cloth anodes to enhance power generation of microbial fuel cells[J]. Electrochemistry Communications, 2007, $9(3): 492-496$.

[18] Crittenden S R, Sund C J. Sumner J J. Mediating electron transfer from bacteria to a gold electrode via a self-assembled monolayer [J] . Langmuir, 2006, 22 (23) : 9473-9476.

[19] Tang X, Guo K, Li H, et al. Electrochemical treatment of graphite to enhance electron transfer from bacteria to electrodes [J]. Bioresource Technology, 2011, $102(3)$ : 3558-3560.

[20] Zhu N W, Chen X, Zhang T, et al. Improved performance of membrane free single-chamber air-cathode microbial fuel cells with nitric acid and ethylene diamine surface modified activated carbon fiber felt anodes[J].Bioresource Technol,2011,102(1):422-426.

[21] Feng Y J, Yang Q, Wang X, et al. Treatment of carbon fiber brush anodes for improving power generation in air-cathode microbial fuel cel1s $[\mathrm{J}]$. Journal of Power Sources, 2010, $195(7)$ : 1841-1844.

[22] Liu J, Qiao Y. Guo C X, et al. Graphene/carbon cloth anode for high-performance mediatorless microbial fuel cell [J]. Bioresource Technology, 2012, 114: 275-280.

[23] Hou J X, Liu Z L, Zhang P Y. A new method for fabrication of grapheme/polyaniline nanocomplex modified microbial fuel cell anodes[J]. Journal of Power Sources 2013, 224(2): 139-144.

[24] Zou Y, Pisciotta J, Baskakov I V. Nanostructured polypyrrole-coated anode for sun-powered microbial fuel cells [J]. Bioelectrochemistry, 2010, 79(1): $50-56$.

[25] Zhang Y, Mo G, Li X, et al. A grapheme modified anode to improve the performance of microbial fuel cel1[J]. Journal of Power Sources, 2011, 196 (13) : 5402-5407.

[26] Lowy D A, Tender L M, Zeikus J G, et al. Harvesting energy from the marine sediment-water interface II : kinetic activity of anode materials[J].Biosensors and Bioelectronics. 2006. 21 (11):2058-2063.

[27] Bibiana Cercado-Quezad, Marie-Line Delia, Alain Bergel . Electrochemical micro-structuring of graphite felt electrodes for accelerated formation of electroactive biofilms on microbial anodes [J]. Electrochemistry Communications . 2011, $13(5)$ : 440-443.

[28] Lai B, Tang X H, Li H R, et al. Power production enhancement with a polyaniline modified anode in microbial fuel cells $[\mathrm{J}]$. Biosens Bioelectron, 2011, $28(1)$ : $373-377$.

[29] Qiao Y, Bao S J, Li C M, et al. Nanostructured polyaniline / titanium dioxide composite anode for microbial fuel cells [J]. ACS Nano, 2008, , 2(1) : 113-119. 